\title{
Bank Guarantee Fund - a new public finance sector entity
}

\author{
Bankowy Fundusz Gwarancyjny - \\ nowa jednostka sektora finansów publicznych
}

\begin{abstract}
This paper is devoted to a change in a catalogue of entities of a public finance sector in Poland. The change was made by adding a new body - the Bank Guarantee Fund. The author indicates which entities belong to the public finance sector in Poland and what is a ratio legis of including the Bank Guarantee Fund in it. The paper also indicates the legal status and tasks of the Bank Guarantee Fund.
\end{abstract}

Keywords: public finance; public finance sector entities; Bank Guarantee Fund; ESA 2010.

Streszczenie. Opracowanie poświęcone jest zmianie w katalogu jednostek sektora finansów publicznych w Polsce, polegającej na dodaniu nowego podmiotu, tj. Bankowego Funduszu Gwarancyjnego. Autor wskazuje, jakie podmioty należą do sektora finansów publicznych w Polsce i jakie jest ratio legis umieszczenia w nim Bankowego Funduszu Gwarancyjnego. W opracowaniu zasygnalizowano także status prawny i zadania Bankowego Funduszu Gwarancyjnego. 
Słowa kluczowe: finanse publiczne; jednostki sektora finansów publicznych; Bankowy Fundusz Gwarancyjny; ESA 2010.

\section{Introduction}

The purpose of activities of the Bank Guarantee Fund is to support stability of the national financial system, in particular by ensuring the functioning of a compulsory deposit guarantee scheme and carrying out compulsory restructuring.

The Act of 11 August 2021 amending the act on public finance and certain other acts ${ }^{1}$ amended, inter alia, provisions of the Act of 27 August 2009 on public finance ${ }^{2}$. As a consequence of the enacted and published amendments, as of 1 January 2022 the catalogue of entities constituting the public finance sector will be extended by the Bank Guarantee Fund. The aim of the study is to determine what motives guided the legislator to include a new entity in the catalogue regulated in Article 9 of the Public Finance Act.

The study is based on a dogmatic and legal research method, as well as on an analysis of the relevant literature.

\section{Public finance sector entities in Poland}

There is no legal definition of the public finance. However, a literature indicates that it is possible to specify the main features of the sector of public finance and the entities comprising $\mathrm{it}^{3}$. The sector of public finance should, therefore, include entities related to public finance, which are involved in public financial management. Public financial management is conducted by the state through its bodies, offices and institutions, local government, social and health care insurance institutions, as well as other entities ${ }^{4}$.

\footnotetext{
Dz.U. [Polish Journal of Laws] of 2021, poz. [item] 1535.

Consolidated text: Dz.U. of 2021, poz. 305 with subsequent amendments.
M. Cilak [in:] Z. Ofiarski (ed.), Ustawa o finansach publicznych. Komentarz, Warsza- wa 2019, p. 128.

4 A. Borodo, Polskie prawo finansowe. Zarys ogólny, Toruń 2014, pp. 16-17.
} 
It is emphasized in the literature that a separation of the public finance sector undoubtedly facilitates an identification of the range of entities obliged to apply certain universal principles of financial management, as these principles are specific for the entities of the public finance sector and specified in the Public Finance Act. The act defines, inter alia principles of operation of public finance sector entities with respect to financial management and detailed accounting, planning and reporting. These rules are binding in the public finance sector ${ }^{5}$.

The public finance sector consists of entities which take diverse legal forms, have different scopes of their activities, as well as apply to a different extent the rules of financial management stipulated in the Public Finance Act. In accordance with Article 9 of the Act of 27 August 2009 on public finance, the sector of public finance in Poland is currently composed of:

1. public authority bodies, including government administration bodies, state control and law protection bodies, and courts and tribunals,

2. local government units and their unions,

3. metropolitan associations,

4. budgetary entities,

5. local government budgetary establishments,

6. executive agencies,

7. budgetary economy institutions,

8. state special purpose funds,

9. the Social Insurance Institution (Zakład Ubezpieczeń Społecznych) and funds managed by it and Agricultural Social Insurance Fund (Kasa Rolniczego Ubezpieczenia Społecznego) and funds managed by President of the Agricultural Social Insurance Fund,

10. the National Health Fund,

11. independent public health care centres,

12. public higher education institutions,

13. the Polish Academy of Sciences and organizational units created by it,

14. state and self-government cultural institutions, and

$5 \quad$ M. Cilak [in:] Z. Ofiarski (ed.), Ustawa ..., p. 129. 
15. other state or self-government legal persons established under separate acts in order to perform public tasks, excluding enterprises, research institutes, institutes operating within the Łukasiewicz Research Network, banks, and commercial law companies.

The catalogue of entities of the public finance sector is not exhaustive as one of the points mentions "other state or local government legal persons established on the basis of separate acts in order to perform public tasks, excluding enterprises, research institutes, banks and commercial law companies" (Article 9(14) of the Public Finance Act). Owing to a such structure of the list of entities, the doctrine points out that the catalogue is imprecise and allows for certain interpretative disputes related to the affiliation (or lack of affiliation) of certain institutions to the public finance sector (this refers, for example, to foundations established pursuant to statutory acts) ${ }^{6}$.

The Bank Guarantee Fund (BGF) will be added to the catalogue of entities forming the public finance sector in Poland by virtue of Article 1(1) of the Act of 11 August 2021 amending the act on public finance and certain other acts. Pursuant to Article 31 of this Act, the amendment is to enter into force on the day following the date of its promulgation, with the exception of enlisted provisions (inter alia, Article 1(1)). This date of entry into force has been set to 1 January 2022. Thus, owing to Article 9 of the Public Finance Act, item 15 the phrase "the Bank Guarantee Fund" will appear in the Public Finance Act on 1 January 2022.

\section{What is BGF?}

Pursuant to the current wording of the Act of 10 June 2016 on the Bank Guarantee Fund, Deposit Guarantee Scheme, and Compulsory Resolution (the "BGF Act" or the "Act") ${ }^{7}$, the Bank Guarantee Fund is a legal person performing tasks specified in the Act (Article 3(1)). Article 3(3) provides

$6 \quad$ E. Malinowska-Misiąg [in:] W. Misiąg (ed.), Ustawa o finansach publicznych. Ustawa o odpowiedzialności za naruszenie dyscypliny finansów publicznych. Komentarz, Warszawa 2019, pp. 47-48.

7 Consolidated text: Dz.U. of 2020 poz. 842 with subsequent amendments. 
that the BGF is not a state legal person and is not a unit of the public finance sector. The purpose of the Fund's operations is to take activities supporting a stability of the domestic financial system. This support is made in particular by ensuring the functioning of the obligatory deposit guarantee scheme and carrying out compulsory resolution (Article 4). The tasks of the BGF are set out in Article 5 of the Act. For instance, they may include the following:

1. performing duties resulting from guaranteeing the deposits, in particular disbursing the guaranteed funds to depositors,

2. control of data included in the calculating systems of entities covered by the guarantee scheme,

3. carrying out compulsory resolution,

4. collecting and analysing information on entities covered by the guarantee scheme and on mortgage banks, in particular for the purpose of formulating analyses and forecasts concerning the banking and the cash sector as well as individual banks and cash funds, and

5. conducting other activities for the stability of the national financial system.

Pursuant to Article 5(3) of the Act, the BGF is obliged to cooperate with other entities acting in support of the stability of the national financial system, entities operating deposit guarantee schemes, as well as with the competent authorities for compulsory resolution, the European Banking Authority and the competent authorities for compulsory resolution for a group, the competent authorities for compulsory resolution for a significant branch, the competent authorities for compulsory resolution for a subsidiary, and the competent authorities for compulsory resolution of a third country.

The authorities of the Bank Guarantee Fund listed in Article 6(1) of the Act are: The Fund Council and the Fund Management Board.

An amendment to the Act of 10 June 2016 on the Bank Guarantee Fund, the deposit guarantee scheme and compulsory resolution will enter into force on 1 January 2022. It will remain clear from Article 3(1) that the fund is a legal person performing the tasks set out in the Act. Article $3(3)$, on the other hand, retains the regulation that the Bank Guarantee 
Fund is not a state legal person. An important change is related to the fact that from 1 January 2022 part of the provision in Article 3(3) indicating that the BGF "is not an entity of the public finance sector" will be removed, but it will be added that it "is not another state organizational unit". The change in Article 3(3) is manifestly a consequence of the amendment of Article 9 of the Public Finance Act, from 1 January 2022. The Bank Guarantee Fund will belong to the entities forming the public finance sector. The introduction of the regulation that the fund "is not another state organizational unit" is intended to emphasize that this entity having the status of a legal person, being from 1 January 2022 a unit of the public finance sector, is not a state entity. Neither it is a local government entity. It is an entity functioning within the banking (financial) sector, just as, for example, universities are entities functioning within the higher education sector.

The purpose of the amendment was no doubt to avoid disputes and doubts as to the legal status of the Bank Guarantee Fund ${ }^{8}$. Thus, the Bank Guarantee Fund will continue to be a legal person (Article 3(1) will remain in force), but it will not have the status of a state legal person or the status of another state organizational unit ${ }^{9}$. This will be directly regulated under the amended Article 3(3).

\section{The Ratio legis of changes in the catalogue of entities of the public finance sector}

The grounds for amending this provision were indicated in the explanatory memorandum to the draft act, which modified, inter alia, Article 9 of the Public Finance $\mathrm{Act}^{10}$. It was emphasized that this solution aims at reducing the differences in the EU and Polish methodologies concerning the

8 Broadly on the legal status of the BGF see e.g. E. Kosieradzka, Bankowy Fundusz Gwarancyjny - podstawowa instytucja zapewnienia bezpieczeństwa finansowego i stabilności systemu bankowego w Polsce, „Studia Iuridica Lublinensia” 2004, No 4, pp. 131-132.

9 It should be noted that in the literature the BGF is sometimes included in the organizational structure of the state - Z. Ofiarski, Istota i zakres kontroli wykonywanej przez Bankowy Fundusz Gwarancyjny, “Białostockie Studia Prawnicze” 2019, No 3, p. 54.

Parliamentary paper No 1277 of 16 June 2021. 
public finance sector, and thus on calculating the public deficit and debt ${ }^{11}$. Despite the current absence of the Bank Guarantee Fund from the catalogue of entities of the public finance sector (the amendment of Article 9 will come into force on 1 January 2022) this entity is already a part of the public finance sector according to the EU methodology. Moreover, it should be noted that many years ago it was recognized as a unit that meets the functional criteria for inclusion in the general government sector.

In the explanatory memorandum to the draft law it was also indicated that in accordance with the EU requirements (laid down in the Council Directive 2011/85/EU of 8 November 2011 on requirements for budgetary frameworks of the Member States ${ }^{12}$ ) the stabilizing expenditure rule $(\mathrm{SRW})^{13}$ should cover as much of the general government sector as possible (ESA 2010 methodology). It is worth mentioning that the ESA 2010 provides, inter alia, a methodology on common standards, definitions, classifications, and accounting rules which should be used for compiling accounts and tables on a comparable basis for the purposes of the European Union. The origins of common standards for accounting and reporting rules can be traced back to the "United Nations System of National Accounts”, which was used by the EEC and its Member States until 1970. In 1970 the EEC published an official document entitled "European System of Integrated Economic Accounts" (ESA), which was prepared by Eurostat with the cooperation of the national statistical institutions of the EEC Member States. This document was the Community version of the UN System of National Accounts. A revised version of the ESA was pub-

11 The issues of public deficit and debt in the context of Polish and EU regulations are presented, inter alia, in: A. Borodo, Deficyt budżetowy i dług publiczny oraz kompetencje organów władzy do ich kształtowania - w świetle przepisów konstytucji i prawa Unii Europejskiej, „Prawo Budżetowe Państwa i Samorządu” 2013, No 1, pp. 11-24, DOI: 10.12775/PBPS.2013.001; E. Lotko, U.K. Zawadzka-Pąk, Problemy terminologiczne i definicyjne deficytu i długu w polskim i unijnym prawie finansów publicznych, „Prawo Budżetowe Państwa i Samorządu” 2016, No 2, pp. 51-67, DOI: 10.12775/PBPS.2016.009.

12 [2011] OJ L306/41.

13 Expenditure rules have been the subject of numerous studies in Polish literature, see e.g. M. Cilak, Reguły wydatkowe dotyczqce budżetu państwa (na gruncie ustawy o finansach publicznych z 2009 r.), „Prawo Budżetowe Państwa i Samorządu 2013, No 1, pp. 39-56, DOI: 10.12775/PBPS.2013.003. 
lished in 1979 (the so-called ESA Second Edition) and in February 1993 the UN Statistical Commission adopted a new System of National Accounts, allowing for international comparisons of results across all UN Member States. This forced the European Communities to modify the Second Edition of ESA, known as "ESA'95", which was framed as an EU regulation ${ }^{14}$. In September 2014, the new European System of National and Regional Accounts (ESA 2010) replaced the existing ESA'95. The consequence of the implementation of the new system was a revision of national accounts by all European Union countries, including statistics concerning the sector of government and local government financial institutions ${ }^{15}$.

The explanatory memorandum to the bill indicates that in order to ensure the operability of the expenditure rule, when designing the SRW, expenditure fully financed by EU and EFTA funds and expenditure by entities that do not have the capacity to generate high expenditure were excluded from its scope. The explanatory memorandum to the bill also shows that the scope of the SRW has been changing since its introduction in 2013. Firstly, in 2015, the Bank Guarantee Fund was included in the scope of entities covered by the SRW. Secondly, new funds created, entrusted, or transferred to the Bank Gospodarstwa Krajowego (BGK) were automatically included in the SRW. Thirdly, the relative scope of general government expenditure covered by the SRW decreased owing to the creation of new earmarked funds for which no mechanism for automatic extension of the SRW was envisaged. Therefore, the extension of the catalogue of public finance sector entities resulted also from the need to strengthen the effectiveness of the SRW. There is no doubt that the main purpose of the existence and functioning of the stabilizing expenditure rule is to strengthen the macroeconomic discipline of public finance.

The stabilizing expenditure rule is one of the instruments that discipline the management of public funds and ensure the maintenance of appropriate levels of basic indicators related to public finance. It constitutes a useful complement to the catalogue of instruments supporting public

14 C. Kosikowski, Prawo finansowe w Unii Europejskiej, Bydgoszcz-Warszawa 2008, p. 168.

15 O. Leszczyńska-Luberek, Wpływ ESA 2010 na statystykę sektora instytucji rzq̨dowych i samorzqdowych, „Wiadomości Statystyczne” 2015, No 11, p. 1. 
finance discipline, although its independent importance should not be overestimated $^{16}$.

It is justified to state that the inclusion of the Bank Guarantee Fund in the catalogue of entities from the public finance sector is of an organizational nature. There is no doubt that in the light of the EU methodology for many years it has been an element of the public finance sector in Poland. It is also the entity that was, is, and will be taken into account while establishing a stabilizing expenditure rule.

Certainly, the inclusion of the Bank Guarantee Fund in the catalogue of entities of the public finance sector was not intended to increase its role and importance for public finances, as these have already been invaluable for many years.

\section{Conclusion}

From 1 January 2022 The Bank Guarantee Fund will be an entity that, in the light of Article 9 of the Public Finance Act, will form the public finance sector in Poland. The Bank Guarantee Fund will be placed in item 15 of that article.

The inclusion of the Bank Guarantee Fund among the entities of the public finance sector is not a revolutionary measure. For many years this entity has been an important element of the public finance sector. Moreover, the Fund was taken into account while establishing the stabilizing expenditure rule. Therefore, the amendment of Article 9 of the Public Finance Act was aimed at reducing differences in EU and Polish methodologies concerning the public finance sector, and consequently, the calculation of the public deficit and debt. The inclusion of the Bank Guarantee Fund in the catalogue of entities of the public finance sector certainly contributes to the implementation of the principle of transparency of public finance.

It should be stressed that the introduction of the regulation that the fund "is not another state organizational unit" is intended to emphasize

16 W. Misiąg [in:] W. Misiąg (ed.), Ustawa o finansach publicznych. Ustawa ..., p. 397. 
that this entity, which is a legal person being from 1 January 2022 a unit of the public finance sector, is not a state entity - it is an entity functioning within the banking sector (financial).

The purpose of the amendment was certainly to avoid disputes and doubts regarding the legal status of the Bank Guarantee Fund. Thus, the Bank Guarantee Fund will continue to be a legal person (Article 3(1) will continue to apply), but it will not have the status of a state legal person or other state organizational unit. The amended Article 3(3) will regulate this directly.

\section{Bibliography:}

Borodo A., Deficyt budżetowy i dług publiczny oraz kompetencje organów władzy do ich kształtowania - w świetle przepisów konstytucji i prawa Unii Europejskiej, „Prawo Budżetowe Państwa i Samorządu” 2013, No 1, pp. 11-24, DOI: 10.12775/PBPS.2013.001.

Borodo A., Polskie prawo finansowe. Zarys ogólny, TNOiK, Toruń 2014.

Cilak M. [in:] Z. Ofiarski (ed.), Ustawa o finansach publicznych. Komentarz, Wolters Kluwer, Warszawa 2019.

Cilak M., Reguły wydatkowe dotyczq̨ce budżetu państwa (na gruncie ustawy o finansach publicznych z 2009 r.), „Prawo Budżetowe Państwa i Samorządu” 2013, No 1, pp. 39-56, DOI: 10.12775/PBPS.2013.003.

Kosieradzka E., Bankowy Fundusz Gwarancyjny - podstawowa instytucja zapewnienia bezpieczeństwa finansowego i stabilności systemu bankowego w Polsce, „Studia Iuridica Lublinensia” 2004, No 4, pp. 129-142.

Kosikowski C., Prawo finansowe w Unii Europejskiej, Oficyna Wydawnicza Branta, Bydgoszcz-Warszawa 2008.

Leszczyńska-Luberek O., Wpływ ESA 2010 na statystykę sektora instytucji rzq̨dowych i samorzqdowych, „Wiadomości Statystyczne” 2015, No 11, pp. 1-15.

Lotko E., Zawadzka-Pąk U.K., Problemy terminologiczne i definicyjne deficytu i długu w polskim i unijnym prawie finansów publicznych, „Prawo Budżetowe Państwa i Samorządu” 2016, No 2, pp. 51-67, DOI: 10.12775/PBPS.2016.009.

Malinowska-Misiąg E. [in:] W. Misiąg (ed.), Ustawa o finansach publicznych. Ustawa o odpowiedzialności za naruszenie dyscypliny finansów publicznych. Komentarz, C.H. Beck, Warszawa 2019. 
Misiąg W. [in:] W. Misiąg (ed.), Ustawa o finansach publicznych. Ustawa o odpowiedzialności za naruszenie dyscypliny finansów publicznych. Komentarz, C.H. Beck, Warszawa 2019.

Ofiarski Z., Istota i zakres kontroli wykonywanej przez Bankowy Fundusz Gwarancyjny, "Białostockie Studia Prawnicze” 2019, No 3, pp. 53-65. 